\title{
COVID-19 as a Catalyst in the Transition to a Future of Multipolar Global Cooperation
}

\author{
H. E. Shaukat Aziz
}

\begin{abstract}
The challenges of an interconnected globalized world are more wide reaching than ever. They include the growing need to tackle climate change, the spread of extremism, the threat of natural disasters, future pandemics, world cyberattacks and the fallout from conflict. These issues mean there is a need for a global one-stop-shop disaster relief unit, which should be formed under the auspices of the United Nations (UN). This UN global disaster relief unit needs the authority and capacity to help any country around the world - to be able to provide physical help, advance warning and post-disaster management. There is much to be learned from case studies - such as the 2005 Pakistan earthquake, which was the worst in Asia for decades. In another vein, outdated Bretton Woods institutions must be dealt with as they were created for global needs of a world shattered by World War II. These institutions are the multilateral organizations - the United Nations, the International Monetary Fund and the World Bank-and they must be restructured for realities of the revolutionary digital and biosphere age. Crucially, there must be a focus on generating inclusive, equitable growth-something the global technological revolution makes more attainable than before.
\end{abstract}

Keywords Interconnected globalized world $\cdot$ Climate change $\cdot$ Extremism Natural disasters $\cdot$ Future pandemics $\cdot$ World cyber-attacks $\cdot$ Global one-stop-shop disaster relief unit - UN global disaster relief unit 2005 Pakistan earthquake • Bretton Woods $\cdot$ Digital and biosphere age $\cdot$ technology revolution

Even before we faced an unprecedented global shock in the form of COVID-19, the geopolitical norms we had known for decades were making way for a less familiar world.

Three decades after the Berlin Wall fell and Asia gained prominence, the centre of power was no longer automatically weighted towards the West. This was coupled with major countries becoming increasingly siloed, withdrawing from their role on the world stage and turning to increasingly protectionist policies. The role of the old

S. Aziz $(\bowtie)$

Green Templeton College, Oxford University, Wellington Square, Oxford OX1 2JD, UK

(C) The Author(s) 2021

H. Wang and A. Michie (eds.), Consensus or Conflict?, China and Globalization,

https://doi.org/10.1007/978-981-16-5391-9_2 
multilateral alliances was diminishing as they effectively vacated the pitch. At the same time, some of the old Cold War rivalries began to re-emerge.

The global pandemic has only accelerated this shift. Unlike the crises we are more familiar with, it has affected us in a multitude of ways - in addition to the human cost through mass loss of life, the virus has closed borders, halted freedom of movement, disrupted supply chains and diminished consumer confidence.

However, just as a recession leads to less-viable businesses folding, it can also open the door to exciting innovation, so too must we use this pandemic to discard old practices that no longer work and leverage it as a springboard for growth. The time is now to focus on fresh thinking for the future-how to better equip ourselves for another unplanned catastrophe on this scale, how to react faster and more effectively.

\section{Reactions to the Challenges of COVID-19}

The challenges facing us, in our increasingly interconnected and globalized world, are also more wide reaching than ever. They include the growing need to tackle climate change, the spread of extremism, the threat of natural disasters and future pandemics, cyber-attack and the fallout from conflict. The great challenge of our globalized world is that issues which arise in far-flung countries have the potential to affect us all.

Today, we have a chance to build a prosperous and equitable world—all that is needed is collective will. If we fail to improve how we work together, we risk falling behind and being stuck in the past.

The shockwaves that reverberated globally in 2020, making the pandemic unique in its scale, largely boiled down to the porous nature of modern borders, the ease of travel and interconnectivity that we have become accustomed to. They allowed the COVID-19 pandemic to spread to every corner of the globe to an unprecedented extent and to become a truly worldwide problem.

Today, it is important to carefully study the lessons learned from our collective-as well as individual approaches_-and learn how to improve the world's preparedness and capacity to withstand similar pandemics in the future. When we analyse how different governments responded to the challenges of the pandemic, it is hard to generalize about any one country's response, although many have followed similar models of "lockdown" with varying levels of enforcement. But societies have different needs and some were more receptive to the kind of public health measures that have been needed. One universal aspect was that, when such a fundamental and far-reaching crisis happens, people expect their leaders to act, to bring in measures of support and to tackle the crisis head-on.

When a crisis of such proportion hits, governments have to be agile-to disregard old norms, move quickly and do everything they can to save lives, support infrastructure and the fabric of society. It is a race against time and is unlike any normal kind of policy-making. 
In 2020, we saw the importance of the "big state" model take hold across Europe and in the United States as well, where government intervention in the economy, as well as in industry, has been exercised on an unprecedented level. The US witnessed rescue packages not seen since the Marshall Plan as well as direct state intervention in the economy.

\section{Looking Forward to a New Post-pandemic Reconstruction}

As we look forward to the worst of the pandemic being over, we need to reflect on mistakes that were made and learn the lessons of the past year. The need for swift, decisive action in such a crisis is paramount. Governments that took decisions quickly to stop the spread of the virus will be praised in the long run. Those that struggled to show leadership are likely to face the heaviest criticism.

The way decisions were communicated with the public is key-it is not enough to decide on a strategy. Being able to relay it clearly, as well as having people on the ground who you rely on to implement it-from local government to police and border patrol - is important for maximum compliance. Whatever strategy you decide to pursue, you must have buy-in from all relevant stakeholders. The military forces, as well as civil society, should be ready to help in the distribution and support of public services.

Governments must be prepared to think outside the box, whether it is in designing new rescue packages or temporarily relaxing regulations to help the national effort. Technology has been a game changer in many ways, but it also creates new challenges for governments in such a crisis. Getting your message across is harder when everyone sees what other countries are doing differently - in real time. This can result in pressure and criticism of a government that is not pursuing a similarly successful strategy.

But the main lesson is that we need to rebuild our capacity — and willingness - to work together and deal with major crises as citizens of the world. Diseases do not recognize borders and all governments must accept that cooperation is the key to dealing with a pandemic_-we live in a globalized world, and a crisis like this needs a global response.

Past tensions must be set aside and countries must work together to help each other meet medicine and equipment shortfalls. The pandemic should hopefully serve as a wake-up call to all those who think unilateral action is the answer. 


\section{Globalization in a Multipolar World}

I have long argued that a multipolar world is better than a unipolar world. The existence of new world powers could be a source of strength for all nations. The emergence of a new balance of power, which we have been seeing over the past few decades and which will only continue in the 2020s, must be handled maturely by all sides. Instead of seeing each other as rivals, key world players should focus on interacting more closely at the summit level and increasing their use of soft, rather than hard power.

Most importantly, we must not let this crisis - and the economic fallout from itusher in a world of more protectionist inward-looking policies. We have already seen the damage vaccine nationalism can have and the damage it can cause to trust and relationships between countries. Siloing yourself, looking inward and playing to the domestic audience would be a mistake. It risks delivering poor results and ultimately propping up less competitive, and therefore often unviable, industries. In the long run, it stifles innovation, limits growth and, as a result, it keeps living standards low.

Overall, the path to collective prosperity does not lie in insularity, but through embracing the opportunities of globalization. Through this we can ensure competition, increased productivity and the incentive to innovate-ultimately boosting collective prosperity. The globalized nature of our interactions mean traditional borders lose their relevance, which is particularly as a result of technological breakthroughs. You can be in one country and have something delivered from the other side of the world at the touch of a button. This should not be seen as a threat, but rather as a chance to access completely new markets.

\section{Tectonic Shifts in Geopolitics}

We have spent the past decade concerned about changing global power dynamics, as the tectonic plates shifted away from the West and towards Asia, and in particular towards China. Much has been said and written of the "Thucydides Trap", referring to the Ancient Greek historian who, writing about the conflict between Sparta and Athens at the time, posited that conflict is inevitable when rising powers emerge to rival dominant ones. While today this outcome is far from inevitable, the argument deserves our careful attention to prevent tension from escalating into conflict.

While we have seen some "growing pains" as the established powers struggle to learn how to react to the changing world order, there is enough room for China to play a major role alongside the United States, a nation that has enjoyed hegemonic status since the collapse of the Soviet Union. Also, China has a valuable role to interact more with the other five permanent members (P5) of the UN Security Council. and other P5 countries Raising the number of key powers that are able to help us collectively navigate global challenges can ultimately be beneficial. The struggles that nations-particularly in the developing world—are having with 
distributing a COVID-19 vaccine only proves this point. The emergence of more than one global center of power will provide balance to the world and act as a vital source of international strength.

\section{COVID-19 Vaccines as a Bridge to Better Global Cooperation}

Questions must be asked about how COVID-19 started and spread and I welcome continued international efforts to assess this. But the pandemic has already brought us positive examples of how global cooperation can-and should-work. For example, Asian countries that had experience in fighting SARS did a great deal to provide the West with much needed protective equipment as well as personnel, equipment and $\mathrm{R} \& \mathrm{D}$ resources.

These same principles should now apply to the global distribution of the vaccine. Scientists working on the Oxford-Astra Zeneca vaccine have pointed out that it is not enough for any individual country to vaccinate its people. The porous nature of our borders - through trade, travel and human connection-means that only once every corner of the world is vaccinated will we finally be able to close the book on COVID19. The rollout of the vaccine should soon become an automatic occurrence, as we saw with small pox, and will hopefully lead to the eradication of the virus. Countries cannot continue to shut their borders to keep out the virus - this is antithetical to the life and values to which we have become accustomed.

Once the monumental task of the vaccine rollout is complete, and even greater work is done to make sure it is resistant to mutations, governments must take a new look at their approach to international affairs. In recent years, we have seen the major powers of the world growing further and further apart. Cooperation between the P5 (the five permanent members of the UN Security Council) has been a struggle for years and in our hyper interconnected, globalized world, where - as we have seendisease spreads so quickly - the necessity for governments to be on the same page is greater than ever.

There needs to be a renewed effort to build linkages and inter-dependencies, which will serve us well when the next crisis comes along. When already in place, these connections play a key role in enabling cooperation. Increasing interconnectivity can be accomplished by encouraging trade, investment and people-to-people contacteven if it is by Zoom for the moment. These efforts will help shore up a level of trust, which will be invaluable in the event of any future tension. Connectivity is the true safeguard of peace.

As the economic impact from repeated lockdowns begins to sink in, there will be a renewed need for economic cooperation. Many governments have understandably relied on quantitative easing and record levels of borrowing at cheap interest rates to fund their way through the emergency measures needed to tackle COVID-19. The drawback of this is that it can lead to ever-rising inequality. The solution is almost 
universally to go for growth-to expand markets and focus on creating opportunity and jobs. The Belt and Road Initiative (BRI), launched by President Xi Jinping, set a new standard for global cooperation, one which can be replicated by countries around the world. Pakistan has already benefited considerably from the BRI, which includes billions of dollars being deployed in our country. More recently, Pakistan has also benefited from support, expertise and vaccine distribution from China during the health crisis. All of this has further contributed to the strength of the relationship between our two nations and demonstrated how countries with more abundant resources can, and should, help their neighbours, creating a win-win for all involved.

\section{The Role of Multinational Organizations in Fighting COVID-19}

It is important to properly define the role of multilateral organizations during the recent pandemic. Over the past year we have seen how poorly prepared they were to face a global crisis of this proportion. The World Health Organization (WHO) has a particularly important role to play in providing accurate information during a pandemic, supporting the global effort to find a vaccine and then driving its equitable distribution. The WHO should have been miles ahead of everyone else, an authoritative voice in the early days of confusion over a new and unknown enemy. It should have been the source of the most authoritative information, a repository of experience for this whole global effort.

Instead, it was largely missing in action. The WHO is uniquely placed to play a vital role in early detection, targeting and then spreading accurate information as soon as it learns a virus has emerged. It should not be waiting for the virus to start spreading before it acts. By then, it is too late. Unfortunately, the organization's response during the critical early stage of the pandemic-before it became an actual pandemic - was a total failure. By all accounts, the WHO was too passive and too slow to take the necessary steps to contain the spread of the virus.

Going forward, we must find ways to reform the WHO, to sharpen its antenna and broaden its scope. The WHO should become a global clearinghouse of information on preventing, managing and providing relief during pandemics that is accessible to all. The WHO should be encouraged to lead from the front and track the world. For example, the WHO should advise what pandemics are currently active, and their causes, so that we can be pre-emptive, timely and effective.

A new paradigm for a global response to such crises is necessary. One that enables us to act faster and to be more nimble. Clear channels of communication within the WHO must be established, so that countries know whom to alert the moment it has concerns - whether it is about a virus or other public health issue. The response must be instant and well prepared with teams of experts ready to assess the situation and draw up recommendations. 
The key message is that planning and preparedness are vital. And every country must have the tools in place to handle a crisis-before it starts.

Not all countries have the necessary specialists or infrastructure to tackle a pandemic or to quickly vaccinate its people-particularly in the developing world. Nor do they have manufacturers that can produce the necessary equipment or labs that can manufacture vaccines. Initially, even advanced Western countries such as the United Kingdom did not have the manufacturing capacity to produce vaccines and had to effectively develop them from scratch. Not everyone has the resources to do this at speed, which is why there must be a go-to window in the world where they can get help. A one-stop-shop disaster relief unit.

On the back end of the COVID-19 pandemic, we must ensure there is a proactive, empowered organization that can act as a global repository of expertise, providing the right equipment and specialists to any country in the world that needs them. This organization should have expertise in every type of disaster-from pandemics to floods to earthquakes. It should be formed under the auspices of the United Nations, which has the authority and capacity to help any country around the world - to be able to provide physical help, pre-warning and post-disaster management. No country can stand alone in a crisis in our globalized world. This is why disaster management will only succeed if it is a truly global effort.

The need for reform does not only apply to the WHO. Many multilateral organizations and the Bretton Woods institutions created after the Second World War-the United Nations, the International Monetary Fund and the World Bank are outdated and have needed to be reformed for a long time. The pandemic exposed problems that existed both in their structure and ability to respond. Regrettably, meaningful crossborder cooperation also did not start until later on in the crisis, seeming to do little while we see major powers splintering — and struggling to co-exist harmoniously.

\section{The Future of Multilateral Cooperation}

Today we see an unwillingness between the major powers of the day to work together-more than there has been in recent years. Arguably, this leaves space for the United Nations to take on a bigger global role and be a force for good. This should include the other institutions related to the United Nations. Reforming the United Nations structure and encouraging cohesion and cooperation would be a step towards achieving this objective. These institutions should do more to act as peace brokers, bringing adversaries to the table and encouraging engagement on any level. These multilateral institutions can be a true force for good and have an important role to play, but without reform to bring them up to date with the modern world, they will simply not be able to step up in a crisis and react fast enough.

What we increasingly see, as different security, economic or social threats emerge, is that the world is suffering from a leadership deficit. Politicians and decision-makers lack a global perspective and are too focused on short-term domestic political cycles. Such an absence of global, far-sighted leadership inevitably becomes a barrier to 
successful cooperation. This can be seen in Europe with divisions that have yet to heal in the wake of Brexit as well as the recent rifts over vaccine procurement failures. It has also been evident in the relationships between the major economic and political superpowers, including the United States, Russia and China.

This comes at a time when the need for clear, effective and strategic leadership is greater than ever. We need leaders to be able to convince their people into taking these unprecedented — and often painful—-lockdown steps, rally support and work together with their counterparts across the world. They must be able to effectively coordinate national, state and local government-which, as we know, are not always in sync. All of this must be done against the backdrop of remote working — with some government departments working almost entirely from home while implementing complex new policies.

\section{First-Hand Experience in Disaster Relief}

I had first-hand experience of how a government manages the fallout of a major crisis during my time in office as Prime Minister of Pakistan. The tragedy caused by the devastating earthquake of 2005, which led to 73,000 people losing their lives and three million more being left homeless was the worst humanitarian disaster in Pakistan's history and we could not have undertaken the relief effort without coordinated action on a global scale. The fact that it had struck Pakistan's most mountainous and remote areas created an additional logistical hurdle for the relief efforts.

President Musharraf and I realized the scale of the disaster meant we were in urgent need of extra funds. We held a donors' conference in Islamabad, which raised USD 6.5 billion for the relief effort. In this, we realized personally involving world leaders to galvanize support and raise awareness throughout the world was very important. George H.W. Bush, the former President of the United States, personally visited Pakistan. UN Secretary General Kofi Annan also flew to Pakistan specifically to co-chair the donors' conference in Islamabad-which made a big difference to our fundraising efforts. High-profile visitors also came-including the Hollywood actor Ben Kingsley all helping draw global attention to the scale of the disaster.

Volunteers and medical professionals flew in from across the world-including Saudi Arabia, Jordan, Turkey, the United States, the UK and other European nations. From countries, such as, China, the UAE, Korea, Brazil, Iran, Japan and Malaysia people from all walks of life came to help out. Some set up field hospitals overnight, others provided vital medical aid and humanitarian assistance on an astonishing scale. Charities like Doctors Without Borders were invaluable, while The World Food Programme and the United Nations provided vital aid and expertise. It was a truly global effort.

We also realized the Government had to be visible on the front line-to show leadership and decisive action. Every day-for months-President Musharraf and I, along with the Cabinet, were active, flying out by helicopter to newly affected areas to view temporary shelters and hospitals. After the earthquake, we set up a specially 
dedicated agency within the government to deal exclusively with future natural disasters. The key element of any disaster management effort is coordination and knowing whom to access for information and logistics. It is little use having doctors and volunteers who wish to help without knowing where to go in the relief effort and with no clear channel to report to. Countries and governments must try to plan ahead to ensure essential equipment and expertise is available when and where it is needed.

Pakistan's armed forces also played a vital role_-we relied heavily on the medical corps, helicopter units and search and rescue teams. The disaster demonstrated vividly how a country's military forces should also be specifically trained to provide emergency aid - this lesson has once again been made clear during the global pandemic. Many countries have found the military support invaluable in coordinating logistical side of the fight against COVID-19 and the subsequent vaccine rollout. That positive experience should be built upon to deliver a permanent benefit for all humanity out of COVID-19. It could be a catalyst to create a global one stop disaster relief unit.

\section{Threats and Solutions for 2021 and Beyond}

Looking towards 2021 and beyond, we are increasingly faced with growing global threats like climate change, terrorism, nuclear proliferation, cyber-attacks and natural disasters that could create problems for the future and disrupt prospects for peace and progress. Even as many countries remain in the grip of the COVID-19 pandemic, we must not let these other pressing issues take a back seat. The more we allow ourselves to look inward and focus on our internal problems, the greater these global challenges will become. These are not issues you can sweep under the rug, or leave for a few years while we focus on other problems - they need to be urgently addressed. And no one country has the ability to resolve them alone.

For successful cooperation, it would help to have a renewed focus on collaborative efforts regarding issues of common interest. For example, climate change threatens our entire planet. Major carbon emitting countries must take joint action to reduce emissions and build a world economy based on green energy. Warm words and high-profile summits are not enough — a comprehensive strategy to achieve environmentally sustainable growth is urgently needed.

The world's population is growing rapidly and developing countries, in particular, are witnessing a demographics boom. Where governments make a concerted effort to invest in the education and health of their peoples, growing populations can contribute to more rapid economic growth and development. Where they do not, growing legions of the poor and jobless can fuel conflict, terrorism and turmoil. It has become essential, therefore, to plan and execute programmes for the inclusive and equal development of all the peoples of the world-with a clear and special priority for the poor.

There needs to be a new architecture for global cooperation-meaning we must also resolve long-standing tensions and differences and manage any potential points of tension through diplomacy and dialogue. In any areas of potential conflict, the 
method of communication between key countries should be institutionalized to encourage frequent contact, dialogue and discussion to prevent conflict escalating from little more than misunderstanding. Initiatives such as joint production for exploiting undersea hydrocarbons in contested areas could help smooth over tensions.

One of the most serious international challenges that faces us all is the failure to curtail the crisis in the Middle East. The region has been traumatized by decades of conflict and the wounds of unsettled long-standing disputes, military interventions and regime changes. Now the economic damage of the pandemic risks throwing the region into a new wave of instability. There is as yet no overarching design to restore peace and stability in the region. Instead, we see major global powers withdrawing from a mediating role. Instead of withdrawing, we must to develop a sense of collective responsibility. Failure to navigate the changes in the geopolitical world order will not only make it harder for us to collectively face security challenges, it could also open us up to new risks.

As COVID-19 has shown, some of the greatest challenges we face could also be opportunities to build a better, more stable world. No change is easy or painless - it requires a lot of political will, buy-in from the important stakeholders in multiple countries and, above all, strategic leadership. Let us see this as a chance to develop a new vision of the world. One that will reshape the global economy to make the most of the opportunities we are presented with, and that guides us through the challenges. One that will create progress and growth that is equitable and fair for all.

There needs to be informed discussion of bigger picture solutions at the highest levels and how they can be implemented. It is crucial that we focus on generating inclusive, equitable growth-something the technological revolution makes more attainable than ever before. If handled correctly and coupled with prudent policies and regulation, it can help transform society. Unlocking these opportunities will not only help us on our path to a new global order-it will ensure peace, stability and progress for decades to come.

H. E. Shaukat Aziz was elected as Prime Minister of Pakistan and served from 2004-2007, following five years as Finance Minister from 1999. Mr. Aziz was the first Prime Minister of Pakistan to complete a full term in office. Prior to public service, Mr. Aziz had a 30-year career in global finance. With Citibank he held several senior management positions followed by Chief Executive of the bank's global wealth management business. Mr. Aziz is a director of several businesses and member of advisory boards of various commercial and non-profit entities around the world. Mr. Aziz's book, From Banking to the Thorny World of Politics, was published by Quartet in May 2016. 
Open Access This chapter is licensed under the terms of the Creative Commons AttributionNonCommercial-NoDerivatives 4.0 International License (http://creativecommons.org/licenses/bync-nd/4.0/), which permits any noncommercial use, sharing, distribution and reproduction in any medium or format, as long as you give appropriate credit to the original author(s) and the source, provide a link to the Creative Commons license and indicate if you modified the licensed material. You do not have permission under this license to share adapted material derived from this chapter or parts of it.

The images or other third party material in this chapter are included in the chapter's Creative Commons license, unless indicated otherwise in a credit line to the material. If material is not included in the chapter's Creative Commons license and your intended use is not permitted by statutory regulation or exceeds the permitted use, you will need to obtain permission directly from the copyright holder.

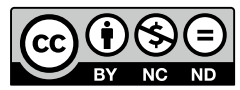

